\title{
Pandemi Döneminde Okul Öncesi Dönem Çocukları ve Annelerinin Psikososyal Açıdan Etkilenme Durumunun Anne Görüişleri Doğrultusunda İncelenmesi
}

\author{
Investigation of the Case of Pandemic's Psychosocial Impact on Preschool Children Based on Mothers' \\ Views
}

\section{ÖZ}

Amaç: Tüm dünyada yaşanan COVID-19 pandemisi nedeniyle ülkeler çeşitli önlemler almıştır. Bu kapsamda uygulanan; sokağa çıkma kısıtlamaları, okulların kapatılması, sosyal yaşamın kısıtlanması, ekonomik zorluklar ve maske takma zorunluluğu gibi önlemler bireyleri psikolojik açıdan büyük ölçüde etkilemektedir. Pandemi süreci gibi beklenmedik ve hayatı olumsuz etkileyen durumların özellikle küçük çocuklar üzerinde stres ve endişe yaratabileceği bilinmektedir. Çocukların yaşadığı endişe ve stres durumlarını en aza indirmek amacı ile süreçte onları yakından gözlemleme olanağı bulunan ebeveynlerinin görüşlerine başvurmanın önemli olduğu düşünülmektedir. Alan yazın incelendiğinde okul öncesi dönem çocukları ve ebeveynlerinin pandemi döneminde psikososyal etkilenme durumunu inceleyen çalışmalar sürecin yeni olması nedeniyle sınırlıdır.

Bu çalışmada pandemi döneminde okul öncesi dönem çocukları ve annelerinin psikososyal açıdan etkilenme durumunun anne görüşleri doğrultusunda incelenmesi amaçlanmıştır. Psikososyal boyut; günlük rutin yaşamdaki değişikliklere bağlı olarak çocuk ve annelerin yaşadığı duygular ve anne-çocuk iletişimi ile sınırlandırılmıştır.

Yöntem ve Araçlar: Araştırmada nitel araştırma deseni kullanılmıştır. Çalışma grubu Kars ili, Merkez ilçesinde yaşayan ve 48-72 ay arası çocukları bulunan 32 anneden oluşmaktadır. Araştırmacılar tarafından hazırlanan yarı-yapılandırılmış görüşme formu ile elde edilen veriler betimsel analiz yöntemi ile analiz edilmiş, sonuçlar yorumlanmıştır.

Sonuçlar: Bu araştırmada, pandemi sürecinde okul öncesi dönem çocukları ve annelerinin psikososyal etkilenme durumu, değişen yaşam koşulları, çocuk ve anne duyguları ve anne-çocuk ilişkisi tespit edilmeye çalışılmıştır. Elde edilen bulgulara göre pandemi sürecinin çocuklar ve anneleri üzerinde psikososyal açıdan etkisi olduğu sonucuna ulaşılmıştır. Bu etkiler, annelerin ve çocukların günlük rutin yaşamlarında, anne-çocuk iletişiminde ve duygusal tepkilerinde farklılıklar olduğu yönündedir.

Anahtar Kelimeler: Anne, Okul öncesi dönem çocukları, Pandemi süreci, Psikososyal etki.

\begin{abstract}
Purpose: Due to the Covid-19 outbreak all over the world, drastic measures were taken by countries. In this context measures such as curfew restrictions, closure of schools, restriction of social life, obligation to wear masks were taken, both these measurements and economical difficulties affected people in a psychological way. It is known that preschool children might show stress and anxiety reactions in the face of difficult life events such as epidemics. It is necessary to observe and follow the changes in children to keep the anxiety and stress as low as possible when the literature is examined, it is seen that due to it being recent there are only a few studies examining the impact of preschool children and mothers from the epidemic process. In this study, it was aimed to evaluate the situation of preschool children and their mothers affected by the epidemic process in line with the opinions of their mothers. Psychosocial Dimension: This research is limited to child and mother's emotions and child-mother relation.

Method and Materials: Case study design was used in the study, which was built on a qualitative research method. The sample of the study consists of 32 mothers with 48-72 months old children in the central district of Kars province. The data were collected through a semi-structured interview form with 32 mothers and the data were collected by content analysis method.

Results: As a result of this research, it was tried to determine the psychosocial influence of preschool children and their mothers during the pandemic process, changing living conditions, change in child's and mother's feelings and mother-child relationship. According to the findings, it was concluded that the pandemic process had a psychosocial effect on children and their mothers. These effects are that there is a difference in the daily routine life of mothers and children, motherchild communication and emotional responses. In line with the results of the research, it is recommended to provide support services to reduce the negative impact of the pandemic process on children, and to ensure coordinated work of psychologists, child development specialists, pediatricians, social workers and educators to raise awareness of mothers.
\end{abstract}

Keywords: Mothers, Preschool children, Pandemic process, Psychosocial impact. 


\section{GíRIŞ}

Aralık 2019 tarihinde Çin'in Wuhan şehrinde ortaya çıan COVID-19'un (Coronavirus Disease) Mart 2020'den itibaren hızla tüm dünyayı etkisi altına alması nedeniyle Dünya Sağlık Örgütü tarafından pandemi ilan edilmiştir (WHO, 2020). COVID-19 vakaları Türkiye'de de hızla artmış, tüm okullar tatil edilmiş, pek çok iş yeri kapatılmış, sokağa çıkma yasağı, maske takma ve hijyen kuralları getirilmiştir.

Sağlık, eğitim ve ekonomi alanındaki önemli etkilerinin yanısıra pandemi, günlük rutin yaşamı da olumsuz yönde etkilediği için insanların panik, kaygı ve depresyon yaşamalarına neden olmaktadır (Di Giuseppe ve diğ., 2020). Bu durumun sonuçları; ebeveyn ve çocukların pandemiye psikolojik tepkisi, pandemiden önce ebeveyn ve çocukların zihinsel ve fiziksel durumu, pandemiden önce ebeveynler ve çocuklar arasındaki etkileşimlerin kalitesi ve son olarak zorluklarla başa çıkmada dayanıklılık gibi faktörlerin birlikte etkileşimiyle belirlenmektedir (Alvarez ve Hunt, 2005). Pandemi sürecinin zorlukları bireylerin yaşam tarzlarını önemli ölçüde değiştirdiği için aile ilişkileri, özellikle de ebeveyn-çocuk ilişkileri büyük oranda etkilenmektedir (Miho ve Thévenon, 2020). Yaşlarının küçük olması nedeniyle okul öncesi dönem çocuklarının etkilenme düzeyi daha fazladır.

Okul öncesi dönem çocukları, kişisel ve fiziksel açıdan olduğu gibi ruhsal açıdan da sürekli değişim ve gelişim göstermektedir (Şahin, 2014). Bu dönem, çocukların yaşamları boyunca kullanacakları temel bilgi ve becerileri kazandıkları bir evre olduğu için oldukça önemlidir (Yavuzer, 2000). Zihin ve dil gelişimi devam ederken buna eşlik eden sınırlı mantıklı düşünme yeteneği de yine okul öncesi dönemde görülmektedir. Yaşantı ve deneyimlerinin eksikliği sebebiyle çocuklar çevresindeki olayları açılamakta zorlanabilmektedir (Yörükoğlu, 2002). Çocukların çevresinde yaşanan ani değişiklikler gelişimlerini de etkiler. Pandemi döneminde okulların kapanmasıyla birlikte hareket kısıtlamaları çocukların günlük yaşam rutinlerinin bozulmasına ve beraberinde farklı problemlerin yaşanmasına neden olmaktadır (UNICEF, 2020). Bu nedenle yaşanan zorlu sürecin çocukların fiziksel, sosyal ve psikolojik iyi olma hali üzerinde doğrudan risk durumu oluşturabileceği öne sürülmektedir (Di Giorgio ve diğ., 2020).

Günlük yaşantıyı olumsuz etkileyen bir süreç ile karşılaşıldığında çocukların endişe ve stres gibi tepkiler göstermesi beklenen bir durumdur ve çocuklar, aile bireyleri ile birlikte tanıdıkları diğer insanlar için de endişe, kaygı, panik ve korku yaşamaktadır. Ayrıca pandemi sürecinin devam etmesi ebeveynlerin de stres düzeyini artırdığ 1 için çocuk ve aile ilişkileri olumsuz yönde etkilenmektedir (Riegler ve diğ., 2020). En fazla etkilenen grup çocuklar olduğu için pandemi sürecinde yaşanan olumsuzlukların en aza indirgenmesinde onların rahatlatılması ve güven duygusu yaşamaları önemlidir. Bunun sağlanabilmesi için günlük rutinlerin devam etmesine özen gösterilmelidir (Olness, Mandalakas ve Torjesen, 2015). Yapılan araştırmalar, ebeveynler tarafından çocuklara yönelik yapılan bilgilendirmelerin de pandemi süreci ile başa çıkmada ve süreci atlatmada olumlu etki yarattığını ortaya koymaktadır (Aral, Aysu ve Kadan, 2020; Wang ve diğ., 2020; Çaykuş ve Mutlu Çaykuş, 2020).

Brooks ve diğerlerine (2020) göre pandemi süreci, çocukların sosyal desteğe en fazla ihtiyaç duydukları bir dönemdir. Bu gibi kriz durumlarında çocuklar arkadaşlarını görmeye, onlarla oyun oynamaya ve insanlarla sosyal iletişim kurmaya daha çok ihtiyaç duyarlar. Alisinanoğlu, Türksoy ve Karabulut’a (2020) göre pandemi süreci, sosyal hayatta değişiklik yarattığı için çocukları psikososyal açıdan da olumsuz etkilemektedir. Çocuklarda görülen problemler; hırçınlık, nedensiz ağlama, bağırma ve öfke nöbeti vb şeklindedir. Ghosh ve diğerlerine (2020) göre; öncelikle ebeveynlerin, çocuk doktorlarının, psikologların, sosyal hizmet uzmanlarının, hastane yetkililerinin ve sivil toplum kuruluşlarının pandeminin psiko-sosyal açıdan çocuklar üzerindeki olumsuz etkilerini azaltmak için önemli görev ve sorumlulukları vardır.

Alan yazında pandemi sürecinde ebeveyn ve çocuklara yönelik yapılan çalışmaların genel olarak pandeminin çocuklar ve aileler üzerindeki etkisi (Akat ve Karataş, 2020; Brown ve diğ., 2020; Budak ve Korkmaz, 2020; Phelps ve Sperry, 2020; Toran ve diğ., 2021) ve çocukların aileleri ile evde yaptıkları etkinlikler üzerine (Gümüşgül ve Aydoğan, 2020; Mart ve Kesicioğlu, 2020) olduğu görülmektedir. Çocukların ve ailelerin yaşanan süreçte psikososyal açıdan nasıl etkilendiğinin araştırılması eğitimciler ve ebeveynlerin çocuğa yapacakları gerek psikolojik gerekse sosyal destek açısından önemlidir. $\mathrm{Bu}$ araştırmanın pandemi sürecinde çocuk ve ebeveynlerin psikososyal açıdan nasıl etkilendiği ortaya koyacağı, aile, öğretmen, araştırmacı ve uygulayıcılara çocuklara destek olurken izleyecekleri süreç konusunda yol göstereceği ve alan yazına katkı sağlayacağı beklenmektedir.

Pandemi sürecinden yaşları gereği en fazla etkilenen grubun okul öncesi dönem çocukları olması nedeniyle bu çalışmanın amacı; pandemi sürecinde okul öncesi dönem çocukları ve ebeveynlerinin psikososyal açıdan etkilenme durumunun ebeveyn görüşleri doğrultusunda incelenmesidir. Psikososyal boyut günlük rutin yaşamdaki değişikliklere 
bağlı olarak çocuk ve ebeveynlerin yaşadığı duygular ve ebeveyn-çocuk iletişimi; çalışma grubu 48-72 ay çocukları bulunan 32 ebeveyn; veriler ise yarı yapılandırılmış görüşme formundaki 9 sorudan elde edilen bilgilerle ile sınırlıdır.

\section{YÖNTEM}

Araştırmada nitel araştırma deseni kullanılmıştır. Nitel araştırmalar 'nasıl' ve 'niçin' sorularını merkezde tutan, araştırmacının kontrol edemediği bir olgu ya da olayı ayrıntılı incelemesini sağlayan araştırma yöntemidir (Yıldırım ve Şimşek, 2016). Nitel araştırmaların temel özelliği; bir durumun ayrıntılı ve derinliğine, durumu etkileyen ortam, olay, bireyler, süreç vb. nin bütüncül bir yaklaşımla araştırılmasıdır (Merriam, 2013). Bu çalışmada psikososyal açıdan çocuk ve ebeveynlerin pandemiden etkilenme durumunun üç kategoride derinlemesine incelenmesi amaçlandığ 1 için nitel araştırma deseni seçilmiştir.

\section{Çalışma Grubu}

Araştırmanın çalışma grubunu, "amaçlı örnekleme ve ölçüt örnekleme" tekniği kullanılarak belirlenen Kars ili Merkez ilçesinde yaşayan 48-72 aylık çocukları olan 32 ebeveyn olușturmaktadır. Ölçüt örnekleme tekniği, araștırma için belirlenmiş özelliklere sahip kişi, olay veya tüm durumları çalıșmak ve gözden geçirmektir (Patton, 2014). Çalışma grubunu oluştururken anne ve babalara araştırmanın amacı birlikte anlatılmış ve katılım onayları istenmiş, ancak sadece anneler gönüllü olarak katılmayı kabul etmiștir. Babaların yer almaması ebeveyn cinsiyeti açısından orantısızlık yaratmıștır. Nitel araștırmalarda nicelik yerine niteliğin önemli olması nedeniyle ve çocuklarla en fazla annelerin vakit geçirip ilgilendiği varsayımıyla baba görüșlerinin olmamasının bir sorun yaratmayacağı düșünülmüștür. Çalıșmaya katılan 32 annenin 48-72 aylık çocuklarının olması, bir okul öncesi eğitim kurumuna devam etmesi ve çevrimiçi görüşmeye uygun imkanlarının olması temel ölçüt olarak belirlenmiştir. Tablo 1'de çalışma grubuna ilişkin demografik bilgilerin dağılımı yer almaktadır.

Tablo 1. Çalışma grubuna ilişkin demografik bilgilerin frekans dağılımı

\begin{tabular}{|c|c|c|}
\hline Demografik bilgiler & & f \\
\hline Annenin öğrenim düzeyi & İlkokul & 9 \\
\hline & Ortaokul & 9 \\
\hline & Lise & 8 \\
\hline & Ön Lisans & 2 \\
\hline & Lisans & 4 \\
\hline Annenin mesleği & Ev hanımı & 27 \\
\hline & Öğretmen & 2 \\
\hline & Devlet Memuru & 3 \\
\hline Annenin yaşı & $20-30$ arasi & 18 \\
\hline & $31-40$ arası & 11 \\
\hline & $41-50$ arasi & 3 \\
\hline Çocuğun yaşı & 60-72 aylık & 20 \\
\hline & $48-60$ aylık & 12 \\
\hline Çocuğun cinsiyeti & $\mathrm{K} 1 \mathrm{Z}$ & 17 \\
\hline & Erkek & 15 \\
\hline Çocuğun günlük teknoloji kullanım sıklığı & 1 saatten az & 7 \\
\hline & 1-2 saat & 6 \\
\hline & $2-3$ saat & 9 \\
\hline & 3-4 saat & 6 \\
\hline & 5 saat ve üzeri & 4 \\
\hline Aile fertleri veya yakınlardan birinin Covid-19 geçirme durumu & Evet & 15 \\
\hline & Hayır & 17 \\
\hline
\end{tabular}

Tablo 1'de görüldügüu gibi görüşme yapılan 9 anne ilkokul, 9 anne ortaokul, 8 anne lise, 2 anne ön lisans, 4 anne lisans mezunudur. Annelerin 27'si ev hanımı olup çalışmamaktadır. 20-30 yaş arasında 18 anne, 31-40 yaş arasında 11 anne, 41-50 yaş aralığında ise 3 anne bulunmaktadır. Annelerinden hakkında bilgi alınan 20 çocuk 60-72 aylık, 12 çocuk 48-60 aylık olup cinsiyet dağılımları 17 kız, 15 erkektir. Çocukların günlük teknoloji kullanma süresinin 
ortalama 2 saatten fazla olduğu tespit edilmiştir. Onbeş çocuğun aile fertleri veya yakınlardan birinin COVID-19 geçirdiği de saptanmıştır.

\section{Veri Toplama Araçları}

Çalışmada veri toplama aracı olarak araştırmacılar tarafından hazırlanan, çalışma grubunun bilgilerini elde etmek için 7 soruluk Demografik Bilgi Formu ve Yarı-yapılandırılmış Görüşme Formu kullanılmıştır. Görüşme formu; amaç doğrultusunda gerekli literatür taraması, alanda uzman kişilerin görüşleri ve Millî Eğitim Bakanlığı tarafından psikososyal bilgilendirme rehberi başlı̆̆ altında hazırlanan Aileler İçin Çocuklara Yardım Rehberi (Özel Eğitim ve Rehberlik Hizmetleri Genel Müdürlüğü, 2020) temel alınarak araştırmacılar tarafından hazırlanmıştır. Form açık uçlu ve çoktan seçmeli olmak üzere toplam 9 sorudan oluşmaktadır. Sorulara ilişkin 3 alt kategori ve buna bağlı alt kategoriler Tablo 2'de yer almaktadır.

Tablo 2. Çalş̧mada kullamilan kategoriler ve alt kategoriler

\begin{tabular}{ll} 
Kategoriler & Alt Kategoriler \\
\hline Annelerin pandemi sürecinden etkilenme durumu & Bilgi kaynakları \\
\hline Pandemi sürecinde anne-çocuk ilişkisi & Pandemi sürecinde hissedilen duygular \\
\hline Çocukların pandemiden etkilenme durumu & Sohbet sılı̆̆ı \\
& Pandemi süreci hakkında sorulan sorular \\
& Çocuğa moral verme \\
\hline Sevgi dolu sözcükler kullanma \\
\hline Birlikte yapılan aktiviteler \\
\hline
\end{tabular}

Araştırma öncesinde belirlenen sorular okul öncesi eğitim alanında çalışan dört ve ölçme-değerlendirme alanında çalışan bir uzmanı tarafından incelenmiş, uygun olanlar araştırma amacı ve nitel araştırmaya uygunluk açısından değerlendirilerek seçilmiştir. Bir soru dört uzman tarafından da uygun bulunmadığı için çıkartılmış ve sonrasında pilot uygulama yapılarak soruların yeterince anlaşılır olup olmadığı, bir bütünlük sağlayıp sağlamadığı kontrol edilmiştir.

Nitel araştırmalarda geçerlilik ve güvenirlik çalışmaları üçgenleme, inandırıcılık, güvenilebilirlik, katılımcı onayı, uzman görüşleri ve zengin betimleme vb. şeklinde olmaktadır (Başkale, 2016; Merriam, 2013; Yıldırım ve Şimşek, 2016). Bu çalışmada geçerlilik ve güvenirlik; soruların hazırlanması ve amaç doğrultusunda uygunluğu açısından ve verilerin çözümleme sürecinde uzman görüşleri boyutu, görüşme sonrasında elde edilen bilgilerin özetlenerek tekrar katılımcılara aktarılması ve teyit edilmesi katılımcı onayı boyutu, araştırma sürecinin detaylı olarak anlatımı ve elde edilen verilerden örnekler verilmesi zengin betimleme boyutu ile ilişkilendirilmiştir. Güvenirlik açısından görüşme kayıtları iki araştırmacı ve bir ölçme değerlendirme uzmanı tarafından bağımsız olarak incelenmiş kategori ve alt kategorilere ait çözümlemeler kontrol edilerek koordinasyon ve uyum sağlanmıştır.

\section{Veri Toplama Süreci}

Araştırma öncesinde etik kurallar gereği Milli Eğitim Müdürlügünnden resmi izin ile birlikte üniversiteden etik kurul raporu alınmıştır. Daha sonra çalışma grubunda yer alan annelerden araştırmaya katılmada gönüllülük onayı alınmıştır. Araştırma verileri 15 Aralık 2020-26 Şubat 2021 tarihleri arasında toplanmıştır. Pandemiden dolayı 48-72 aylık çocukları bulunan 32 anne ile çevrimiçi platformlar aracılığıyla görüşmeler bireysel olarak yapılmış ve onayları doğrultusunda her görüşme hem yazılı hem de sesli-görüntülü olarak kaydedilmiştir. Görüşme süresi ortalama 15-20 dakikadır. Görüşmenin devamında araştırmacılar tarafından görüşmenin kısa bir özeti katılımcıya tekrar edilerek doğruluğu teyit edilmiş ve hemen analiz edilmiştir.

Karşılıklı görüşmenin oluşturabileceği kaygı, zaman ve mekân kısıtlaması gibi etkenlerin pandemi sürecinin sınırlılıkları gereği bu çalışmada olmaması sorulara içten ve samimi cevapların verilmesini kolaylaştırdığı ve araştırmaya olumlu katkı sağladığı düşünülmektedir. 


\section{Veri Analizi}

Verilerin analiz edilmesinde içerik analizi yöntemlerinden betimsel analiz tekniği kullanılmıştır. Betimsel analiz; tamamen orjinaline uygun olarak katılımcıların söylediği, yazdığı, ifade ettiği bilgilerden direk alıntı yapılarak verilerin "betimsel”, bir başka deyişle "tanımlayıcı" analizidir (Kümbetoğlu, 2005).

Çalışmaya katılanlar A1, A2, A3... A4 şeklinde kodlanmıştır. Çocukların ve annelerinin pandemi sürecinden psikososyal etkilenme durumunun anne görüşleri doğrultusunda değerlendirilmesi kapsamında oluşturulan kategori ve alt kategoriler frekans olarak belirlenmiş ve betimsel olarak analiz edilmiştir.

\section{BULGULAR}

Araştırmanın bulguları üç ana kategoride ele alınmıştır. Bu kategorilerle ilişkili alt kategoriler araştırma verileri doğrultusunda belirlenmiş ve bulgular yarı-yapılandırılmış görüşme formundan elde edilen verilere göre analiz edilerek tablolaştırılmıştır.

"Pandemi sürecinde genel olarak hangi kaynaklardan bilgi aldınız?" ve "Pandemi konusunda neler hissediyorsunuz?" sorularına ilişkin alınan cevaplar Tablo 3’te yer almaktadır:

Tablo 3. Annelerin Pandemi Sürecinden Etkilenme Durumu Kategorisine İlişkin Bulgular

\begin{tabular}{llc} 
Alt Kategoriler & Annelerin Görüşleri & f \\
Annelerin etkilendiği bilgi kaynakları & İnternet siteleri & 16 \\
& Televizyon & 15 \\
& Sosyal medya & 7 \\
& Gazete & 1 \\
\hline $\begin{array}{l}\text { Pandemi sürecinde annelerin hissettiği } \\
\text { duygular }\end{array}$ & Aile fertlerini veya yakınlarını kaybetme & 20 \\
& korkusu & 19 \\
& Korku, kaygı ve endişe & 16 \\
& Gelecek korkusu ve kaygısı & 13 \\
& Belirsizlik & 11 \\
& Mutsuzluk & 9 \\
\hline
\end{tabular}

Tablo 3'te "annelerin pandemi sürecinden etkilenme durumu” kategorisine ilişkin iki alt kategorideki bulgular bulunmaktadır. Bu alt kategorilerden biri “annelerin bilgi aldı̆̆ kaynaklar” kategorisidir. Pandemi süreciyle ilgili bilgileri 16 anne internet sitelerinden, 15 anne televizyondan, 7 anne sosyal medyadan ve bir anne de gazetelerden aldığını belirtmiştir.

"Pandemi sürecinde annelerin hissettiği duygular" alt kategorisinde 32 annenin tamamının olumsuz duygular hissettiği görülmektedir. Ayrıca 20 annenin aile fertlerini veya yakınlarını kaybetme korkusu, 19 annenin korku, kaygı ve endişe, 16 annenin gelecek korkusu ve kaygısı, 13 annenin belirsizlik, 11 annenin mutsuzluk, 9 annenin de hastalanma ve ölüm korkusu hissettiği tespit edilmiştir.

Görüşme formundaki "pandemi konusunda çocuklarınızla ne sıklıkla sohbet ettiniz?", "pandemi hakkında çocuklarınızın size soru sormasına izin verdiniz mi?", "genellikle ne tür sorular sordular?", "pandemi sürecinde çocuklarınıza psikososyal destek ve moral vermek için neler yaptınız?”, "çocuklarınıza pandemi sürecinde sevgi dolu cümleleri ne sıklıkla söylediniz?” ve "pandemi sürecinde çocuklarınızla aşağıdakilerden hangisi/hangilerini yaptınız?" sorulara verilen cevaplardan oluşturulan “Anne-Çocuk İlişkisi” kategorisine yönelik bulgular Tablo 4’te yer almaktadır:

Tablo 4. Pandemi Sürecinde Anne-Çocuk İlişkisi/İletişimi Kategorisine İlişkin Bulgular

\begin{tabular}{llc} 
Alt Kategoriler & Annelerin Görüşleri & f \\
Sohbet sıklı̆̆1 & Sık sık konuşuyoruz & 14 \\
& Gerektiği zaman konuşuyoruz & 12 \\
& Nadiren konuşuyoruz & 6 \\
\hline
\end{tabular}




\begin{tabular}{|c|c|c|}
\hline \multirow[t]{4}{*}{ Pandemi süreci hakkında çocukların sordukları sorular } & Hasta olmakla ilgili sorular & 12 \\
\hline & Maskeyle ilgili sorular & 11 \\
\hline & Virüsün ne zaman biteceği ile ilgili sorular & 9 \\
\hline & Okulun açılması ile ilgili sorular & 6 \\
\hline \multirow[t]{3}{*}{ Çocuğa moral verme } & Etkinlik yapma & 12 \\
\hline & Hiçbir şey yapmama & 11 \\
\hline & Düşünmemesi gerektiğini söyleme & 9 \\
\hline \multirow[t]{5}{*}{ Sevgi dolu sözcükler kullanma } & Sürekli kullanıyoruz & 15 \\
\hline & Gerektiği zaman kullanıyoruz & 8 \\
\hline & Sik sık kullanıyoruz & 6 \\
\hline & Nadiren kullanıyoruz & 3 \\
\hline & Hiç kullanmıyoruz & 0 \\
\hline \multirow[t]{6}{*}{ Pandemi sürecinde çocuklarla yapılanlar } & Öz bakım (el-yüz yıkama, giyinme vb.) & 25 \\
\hline & Sorumluluk verme & 20 \\
\hline & $\begin{array}{l}\text { Çocuklarınızın önünde aşırı düzeyde haber } \\
\text { takip etme }\end{array}$ & 14 \\
\hline & Düzenli beslenme & 13 \\
\hline & Uyumaya yönelik model olma & 8 \\
\hline & $\begin{array}{l}\text { Aşırı kaygı ve bunun gibi sorunlarda uzmana } \\
\text { başvurma }\end{array}$ & 2 \\
\hline
\end{tabular}

Tablo 4'te "pandemi sürecinde anne-çocuk ilişkisi/iletişimi" kategorisine ilişkin beş alt kategoride elde edilen veriler yer almaktadır. Bu alt kategorilerden biri, annelerin çocuklarıla pandemi hakkında sohbet etme (iletişim) durumunu içeren "sohbet sıklığı" alt kategorisidir. Elde edilen bulgular tüm annelerin pandemi süreciyle ilgili olarak çocuklarla sohbet ettiği yönündedir. 14 anne sık sık, 12 anne gerektiği zaman, 6 anne nadiren sohbet ettiğini bildirmiştir.

İkinci alt kategori "pandemi hakkında çocukların sordukları sorular" alt kategorisidir. Bu alt kategoride 12 anne çocuklarının hasta olmakla ilgili, 11 anne maske takma ile ilgili, 9 anne virüsün ne zaman biteceği ile ilgili, 6 anne ise okulun açılması ile ilgili sorular sorduğunu ifade etmiştir.

Örnek yanıtlar: A3: "Çoğu şeyin ne olduğunu internetten öğrenmişler. Maskeyle alakalı soruları çok soruyor." A7: "Anne böyle yapsak hasta olur muyuz? Buraya dokunsak mikrop kapar miyız?" A10: "Virüs ne zaman bitecek, okulumu özledim, ne zaman açılaca, nasıl dışarı çıkacağız gibi sorular soruyor." A13: "Evet. Dedemlere ne olacak? diyordu sürekli. Ben bazen ağladı̆̆ımda da neden ağladiğımı soruyordu. Virüsün bitip bitmeyeceğini de çok soruyor." A:24 "Neden okula gidemiyorum, dışarı neden çıkamıyorum diye soruyor, ama açıklama yaptıktan sonra sorun çıkarmıyor." A27: "Anne bu hastalık ne zaman bitecek ne olur Covid bitsin ve dışarı çıkalım, okula gidelim diye soruyor sürekli."

Üçüncü alt kategori "pandemi sürecinde çocuğa moral verme" alt kategorisidir. Bununla ilgili olarak 12 anne moral vermek için çocuklarıyla etkinlik yaptığını, 11 anne hiçbir şey yapmadığını, 9 anne ise çocuğuna düşünmemesi gerektiğini söylediğini ifade etmiştir.

Örnek yanıtlar: A3: "Herhangi bir şey yapmıyorum, dışarı çıkmayın diyorum." A12: "Normal geçiriyoruz günlerimizi, bir şey yapmıyorum." A14: "Korkmamalarını, bu sürecin geçeceğini anlatmaya çalışıyorum, sevdiği şeyleri yapıyorum, oyun oynuyoruz, sık sık sohbet ediyoruz, zaman böyle geçiyor." A20: "Geçeceğini ve hayatımızın normale döneceğini ve bunları düşünmemesini söylüyorum." A27: "Resim yaptırıyorum, oyun oynatıyorum.” A29: "Evde sıkılmasin diye oyunlar oynatıyorum."

Dördüncü alt kategori "pandemi sürecinde çocuğa sevgi dolu sözcükleri kullanma sıklığı" alt kategorisidir. 15 anne sevgi sözcüklerini sürekli kullandığını, 8 anne gerektiği zaman kullandığını, 6 anne sık sık, 3 anne ise nadiren sevgi sözcüklerini kullandığını belirtmiştir.

Beşinci alt kategori "pandemi sürecinde çocuklarla birlikte yapılanlar" alt kategorisidir. Bu alt kategoride 25 anne çoğunlukla çocuklarıyla öz bakım üzerine çalıştığını, 20 anne çocuklarına sorumluluk verdiğini, 14 anne çocukların önünde aşırı düzeyde haber takip ettiğini, 13 anne çocuklarını düzenli beslenmeye teşvik ettiğini, 8 anne çocuklarına uyumaya yönelik model olduğunu, 2 anne de çocukları için yaşanan aşırı stres ve kaygı gibi sorunlardan dolayı bir uzmana başvurduğunu belirtmiştir.

Örnek cümleler: A5: "Bu süreçte beslenmesi çok önemli. Tüm aile beslenmemize dikkat ediyoruz, besin takviyesi almaya 
çalışıyoruz." A10: "Haberleri izlerken yanımda oluyor. Her gün bugün acaba vaka sayısı kaç diye aşırı endişeleniyoruz ve sürekli haberlerin başında bekliyoruz." A15: "Özellikle el yıkaması için, eve geldiğinde üstünü değiştirmesi için çalışmalar yapıyorum." A20: "Bu süreci tedbirle atlatacağımız için onunla temizlik etkinlikleri yapıyorum. Çıktı alıp bunların üstünden anlatıyorum."

Görüşme formundaki "pandemi sürecinde çocuklarınızın günlük yaşamında herhangi bir değişiklik oldu mu?” ve "pandemi sürecinde çocuğunuzda aşağıdaki davranış/tepkilerden hangilerini gözlemlediniz, belirtiniz?" sorularına verilen cevaplardan oluşturulan "çocukların etkilenme durumu" kategorisine ilişkin bulgular Tablo 5 'te yer almaktadır:

Tablo 5. Pandemi Sürecinde Çocuklarm Etkilenme Durumu Kategorisine İlişkin Bulgular

\begin{tabular}{|c|c|c|}
\hline Alt Kategoriler & Annelerin Görüşleri & f \\
\hline \multirow[t]{6}{*}{ Günlük yaşamda değişiklikler } & Okul saatinde değişiklikler & 17 \\
\hline & İnternet kullanım saatinde değişiklikler & 17 \\
\hline & Oyun aktivitesinde değişiklikler & 14 \\
\hline & Oyun saatinde değişiklikler & 12 \\
\hline & Uyku saatinde değişiklikler & 11 \\
\hline & Yemek saatinde değişiklikler & 8 \\
\hline \multirow[t]{17}{*}{ Tepkilerinde değişiklikler } & Sürekli televizyon izlemeyi isteme & 17 \\
\hline & Sürekli ellerini yıkama davranışı & 15 \\
\hline & Ebeveynlerin yanından hiç ayrılmak istememe & 13 \\
\hline & Sürekli ağlama ya da ağlamaklı olma & 9 \\
\hline & Huzursuz, huysuz ve sinirli olma & 9 \\
\hline & $\begin{array}{l}\text { Aşırı ürkeklik ya da korkuların başlaması (yalnız kalma, karanlık, } \\
\text { hayaletler vb.) }\end{array}$ & 7 \\
\hline & Hastalanma korkusu & 7 \\
\hline & Sürekli pandemiye dair abartılı hikâyeler anlatma & 6 \\
\hline & $\begin{array}{l}\text { Çocuğun yaptığı resimlerde değişiklikler (koyu renklerin } \\
\text { kullanımı, farklı nesnelerin çizimi vb. }\end{array}$ & 5 \\
\hline & $\begin{array}{l}\text { Takıntı geliştirme (sık el yıkama, sık dezenfektan kullanımı, hiçbir } \\
\text { şeye dokunmak istememe vb.) }\end{array}$ & 5 \\
\hline & Karın ağrısı ya da baş ağrısı gibi fiziksel şikayetler & 5 \\
\hline & $\begin{array}{l}\text { Oyunlarda sürekli pandemi sürecini, hastalığı canlandırma/ } \\
\text { yaşama }\end{array}$ & 4 \\
\hline & Öfke nöbetleri geçirme ya da saldırgan davranışlar & 4 \\
\hline & Dişarı çıkmak istememe & 4 \\
\hline & Parmak emme, tırnak yeme, geceleri altını 1slatma vb & 1 \\
\hline & Odasından çıkmama, çıkmak istememek & 0 \\
\hline & Televizyonun açılmasını istememe & 0 \\
\hline
\end{tabular}

Tablo 5’te görüldüğü gibi "pandemi sürecinde çocukların etkilenme durumu” kategorisine ilişkin iki alt kategoride elde edilen bulgular sunulmuştur. Bu alt kategorilerden ilki olan "pandemi sürecinde yaşanan değişiklikleri içeren, günlük yaşamda değişiklikler" alt kategoriden elde edilen bulgulara göre 17 anne çocukların okul saatinde değişiklik ve internet kullanım saatinde değişiklik olduğunu, 14 anne oyun aktivitelerinde, 12 anne oyun saatinde, 8 anne ise yemek saatinde değişiklik olduğunu ifade etmiştir.

"Pandemi sürecinde çocukların davranış/tepkilerindeki değişiklikler" alt kategorisine göre; 17 anne çocuklarının sürekli televizyon izlemek istediğini, 15 anne sürekli ellerini yıkama davranışı gösterdiğini, 13 anne çocuğun ebeveynlerinin yanından hiç ayrılmak istemediğini, 9 anne çocuklarının sürekli ağladığını ya da ağlamaklı olduğunu, 9 anne huzursuz, huysuz ve sinirli olduğunu; 7 anne aşırı ürkek davranışlar ya da korkuların başladığını, 7 anne çocuğun hastalanma korkusu yaşadığını; 6 anne çocuğunun sürekli pandemiye dair abartılı hikayeler anlattığını, 5 anne çocuğun yaptığı resimlerde değişiklikler olduğunu, 5 anne temizlikle ilgili takıntılar geliştirdiğini, 5 anne karın ağrısı, baş ağrısı gibi şikayetlerinin olduğunu, 4 anne oyunlarda sürekli pandemi sürecini canlandırdığını, 4 anne öfke nöbetleri geçirme ya da saldırgan davranışlar gösterdiğini, 4 anne dışarı çıkmak istemediğini, bir anne ise parmak emme, tırnak yeme, geceleri altını slatma vb. davranışlarının başladığını belirtmiştir. Anneler bu süreçte çocuklarında odasından çıkmama, çıkmak istememe ve televizyonun açılmasını istememe gibi tepkilerle karşılaşmadıklarını belirtmiştir. 


\section{SONUÇ, TARTIŞMA VE ÖNERILER}

Okul öncesi dönem çocukları ve annelerinin pandemi sürecinden etkilenme durumlarının anne görüşleri doğrultusunda incelenmesini amaçlayan bu çalışmada aşağıdaki sonuçlar elde edilmiştir.

Annelerin pandemi sürecinden etkilenme durumu kategorisinden elde edilen sonuçlar incelendiğinde annelerin çeşitli olumsuz duygular yaşadığı, en fazla hissedilen duygunun aile fertlerini ve yakınlarını kaybetme korkusu olduğu ve buna bağlı olarak korku, kaygı ve endişelerinin arttığı, gelecek kaygısının da sıklıkla yaşandığı tespit edilmiştir. Elde edilen bu sonuç, Brown ve diğerleri (2020), Tarkoçin, Alagöz ve Boğa (2020) tarafından yapılan pandemi sürecinin ebeveynler üzerindeki olumsuz etkisini inceleyen araştırmaların sonuçlarıyla paralellik göstermektedir. Ayrıca Amakiri ve diğerleri (2020), Demirbaş ve Koçak’n (2020) yetişkinlerde pandemi sürecinde korku, kaygı ve endişenin sıklıkla görüldügünü ortaya koyan çalışmaları da bu sonucu destekler niteliktedir. Erol’a (2020) göre, bu süreçte ebeveynlerin korku ve kaygıları tüm aile üyeleri için stres ve psikolojik sıkıntı kaynağı olabilmektedir. Keleşoğlu ve Adam (2020) pandemi sürecindeki ebeveyn duygu durumlarının, çocukları ile birlikte evde eğlenmek için geçirdikleri zamanı da etkilediğini ifade etmektedir. Bu nedenle ebeveynlerin duygu durumlarından çocuklar büyük ölçüde etkilenmektedir.

Araştırmada pandemi sürecinden etkilenme durumu kategorisinde, anneler pandemi sürecinin olumsuzluklarıyla başa çıkabilmek için çeşitli bilgi kaynaklarından etkilendiklerini belirtmişlerdir. En fazla etkilenilen bilgi kaynağının internet siteleri ve televizyon olduğu görülmektedir. Anne-çocuk ilişkisi kategorisinden elde edilen sonuçlar incelendiğinde, annelerin bu süreçte çocuklarıyla sık sık pandemi hakkında sohbet ettiği, ayrıca çocukların pandemi sürecinin zorluklarıyla başa çıkabilmeleri için bilgilendirme yöntemini etkin bir şekilde kullandığ tespit edilmiştir. Yıldız ve Beştaş่ın (2020) yapmış olduğu araştırmada hasta olma korkusunun çocukları olumsuz yönde etkilediği sonucu araştırmanın bulguları ile paralellik göstermektedir. Bu sonuç, çocukların etkilenme durumunun doğal olarak sorularına yansıması șeklinde yorumlanabilir. Ebeveynlerin çocukların pandemi süreci ile ilgili soru sormalarına izin vermesi ve bu soruları doğru ve bilinçli bir şekilde cevaplandırmaları bu süreci desteklemeye yardımcı olmaktadır (Özel Eğitim ve Rehberlik Hizmetleri Genel Müdürlüğü, 2020).

Pandemi sürecinde anne-çocuk ilişkisi/iletişimi kategorisinde çocuklara moral vermek için sadece 12 anne evde etkinlikler yaptığını, 20 anne ise hiçbir şey yapmadığını, çocuğuna bu süreci düşünmemesini söylediğini ifade etmiştir. Bu sonuç, evde çocukların gelişimini desteklemek amacıyla etkinlik yapan annelerin sayısının yetersiz olduğunu, çoğunluğunun da bilinçsiz bir yaklaşım sergilediğini göstermektedir. Pandemi sürecinin sağlıklı bir şekilde atlatılabilmesi için ebeveynlerin çocuklarına hikâye anlatma, resim yapma, şarkı söyleme vb. gibi etkinlik yapmaları önemlidir (Ghosh ve diğ., 2020; Wang ve diğ., 2020). Bu çalışmada annelerin pandemi sürecinde çocuklarıly genellikle öz bakım becerileri ile ilgili çalışmalar yaptığı ve sorumluluk verme konusunda çocukları desteklediği görülmüştür. Anneler çocuklarının yanında aşırı düzeyde haber takip ettiğini belirtmiştir. Oysaki haberler özellikle okul öncesi dönem çocukları için sakıncalı (korku, şiddet, olumsuz örnek vb) ve yaşına uygun içeriğe sahip değildir. Çocuklar pandemi süreci ile ilgili haberler izlediğinde aşırı korku, kaygı ve stres yaşamaktadır. Wang ve diğerlerine (2020) göre çocuklar sürekli olarak pandemi süreci ilgili haberlere maruz kaldığında, ebeveynler çocukların kaygısını yönetmeli ve gerektiğinde çocukların endişelerini hafifletmek amacıyla doğrudan görüşmeler yapmalıdır. Bu çalışmada, annelerin pandemi sürecinde çocuklarına sevgi sözcükleri kullandığı ve duygusal olarak desteklediği sonucuna ulaşılmıştır.

Çocukların pandemi sürecinden etkilenme durumu kategorisinden elde edilen sonuçlar incelendiğinde çocukların günlük yaşantısında ve davranış/tepkilerinde çeşitli değişiklikler olduğu tespit edilmiştir. Çocukların günlük yaşantısında görülen değişiklikleri anneler; okul saatinde değişiklikler, internet kullanım saatinde değişiklikler, oyun aktivitesinde değişiklikler, uyku ve yemek saatinde değişiklikler olarak ifade etmişlerdir. Okul saatinde olan değişikliklerin ülke genelinde alınan kararlar nedeniyle olduğu bilinmektedir. Çocukların internet kullanım süresinde değişiklik (artış) olması Başaran ve Aksoy (2020) ile Baysal, Ocak ve Ocak’ın (2020) araştırma bulgularıyla benzerlik göstermektedir. Çocukların bu süreçte çok fazla internet kullanmak istemesi beraberinde birçok sorunun yaşanmasına neden olmaktadır. Aral, Aysu ve Kadan’a (2020) ve Ghosh ve diğerlerine (2020) ve Ylldız ve Beştaş’a (2020) göre, pandemi sürecinde çocukların internet kullanım süresinde biraz esneklik yapılsa da, bu saatler sürecek düzeyde olmamalı ayrıca ebeveynler çocukların teknolojiyi ve sosyal platformları kullanma isteğine yönelik çeşitli önlem ve tedbirleri de almalıdır.

Pandemi sürecinde çocukların tepkilerinde görülen değişiklikler incelendiğinde çocukların; sürekli televizyon izlemek istediği, sıklıkla ellerini yıkama eğilimi gösterdiği ve ebeveynlerinden hiç ayrılmak istemediği sonucuna ulaşılmıştır. Bu sonuç, Demirbaş ve Koçak’in (2020) ve Ghosh ve diğ. (2020) pandemi sürecinin çocuklar üzerindeki 
etkisini inceleyen çalışmalarıyla benzerlik göstermektedir. Imran, Zeshan ve Pervaize (2020) göre bu süreçte çocukların anne-babadan ayrılmak istememe gibi eğilimleri sıklıkla gözlenebilir. Buna ek olarak çocuklarda sürekli el yıkama vb gibi davranışları görme sıklığı artabilir. Erol'a (2020) ve Pembecioğlu (2020) göre çocuklar yaşları gereği tam olarak kendilerini ifade edemedikleri için yaşadıkları olumsuz, kaygılı ve stresli süreçte çeşitli davranış ve uyum bozuklukları gösterebilirler. Bu olumsuz süreci kontrol etmek ebeveynlerin en önemli görevi olmalıdır.

$\mathrm{Bu}$ araştırmada pandemi sürecinde annelerin etkilenme durumu ve anne-çocuk ilişkisi/iletişimi analiz edilmiş, özellikle çocuklar üzerinde olumsuz etkileri olduğu sonucuna ulaşılmıştır. Bu etkilerin hem çocukların günlük rutin yaşamında hem de duygusal davranışsal tepkilerinde ortaya çıtığı tespit edilmiştir.

Araştırma sonuçları doğrultusunda araştırmacılar ve uygulamacılara

- Pandemi sürecinin çocuklar üzerindeki duygusal ve sosyal etkilerini azaltacak programlar geliştirilmesi,

- Özellikle sosyal medya yayınları ve televizyon programlarının aileleri ve çocukları bilinçli hale getirecek şekilde hazırlanması,

- Ebeveynleri bilinçlendirmek için pandemi sürecinin çocuklar üzerindeki olumsuz etkisini azaltmalarına yönelik destek hizmetlerinin sağlanması,

- Psikologlar, çocuk gelişim uzmanları, çocuk doktorları, sosyal hizmet uzmanları ve eğitimcilerin iş birliği içerisinde koordineli çalışmalarının sağlanması,

- Millî Eğitim Bakanlığı tarafından çocuklara yönelik bilgilendirme ve bilinçlendirme çalışmalarının yaygınlaştırılması,

- Öğretmenlerin pandemi sürecinde eğitim ve çocuklara yaklaşımlar konusunda bilgilendirilmesi, bilinçlendirilmesi,

- Araştırmacılara pandemi sürecinin çocuklar üzerindeki psikolojik etkisinin daha geniş örneklem grupları ile yapılması, pandemi süreci sona erdikten sonra da belirli periyotlarda bu etkilerin kalıcı olup olmadığını tespit ve takip araştırmaları yapmaları önerilmektedir.

\section{KAYNAKÇA}

Akat, M. ve Karataş, K. (2020). Psychological effects of covıd-19 pandemic on society and its reflections on education. Journal of Turkish Studies.1-13.

Alisinanoğlu, F., Türksoy, E., Karabulut, R. (2020). Pandemi Sürecinde Çocukluk Dönemi Korkuları. Uluslararası Beşeri Bilimler ve Eğitim Dergisi, 6 (14), 447-568.

Alvarez, J. ve Hunt, M. (2005). Risk and resilience in canine search and rescue handlers after 9/11. Trauma Stress 2005; 18: 497-505.

Amakiri, P. C., Ezeoke, A., Chude, C. F. \& Anoka, K. (2020). Psychological effect of pandemic COVID-19 on families of health care professionals. British Journal of Psychology Research, 8(2), 1-7.

Aral, N, Aysu, B ve Kadan, G. (2020). Covid 19 sürecinde çocuklar: gelişimsel ihtiyaçlar ve öneriler. Çankırı Karatekin Üniversitesi Sosyal Bilimler Enstitüsü Dergisi, 11 (2), 360-379.

Başaran, M., Aksoy, A.B. (2020), Anne babaların korona virüs (covid-19) salgını sürecinde aile yaşantılarına ilişkin görüşleri, Uluslararası Sosyal Araştırmalar Dergisi, 13 (71), 667-681.

Başkale, Hatice (2016). Nitel Araştırmalarda Geçerlik, Güvenirlik ve Örneklem Büyüklüğü. Dokuz Eylül Üniversitesi Hemşirelik Fakültesi Elektronik Dergisi, DEUHFED, 9(1), 23-28

Baysal, E, A., Ocak, G. ve Ocak, İ. (2020). Covid-19 salgını sürecinde okul öncesi çocuklarının eba ve diğer uzaktan eğitim faaliyetlerine ilişkin ebeveyn görüşleri. Uluslararası Sosyal Bilimler Eğitimi Dergisi, 6 (2), 185-214.

Brown S.M., Doom, J., Watamura, S.E., Lechuga-Pena, S. Ve Koppels, T. (2020). stress and parenting during the global COVID-19 pandemic. Child abuse \& neglect, 104699.

Budak, F ve Korkmaz, Ş. (2020). Covıd-19 pandemi sürecine yönelik genel bir değerlendirme: Türkiye örneği. Sosyal Araştırmalar ve Yönetim Dergisi, (1), 62-79.

Brooks, S. K., Webster, R. K., Smith, L. E., Woodland, L., Wessely, S., Greenberg, N., \& Rubin, G. J. (2020). The psychological impact of quarantine and how to reduce it: rapid review of the evidence. Lancet (London, England), 395(10227), 912-920. 
Çaykuş, E. ve Mutlu Çaykuş, T. (2020). Covıd-19 pandemi sürecinde çocukların psikolojik dayanıklılığını güçlendirme yolları: ailelere, öğretmenlere ve ruh sağllğı uzmanlarına öneriler. Avrasya Sosyal ve Ekonomi Araşttrmaları Dergisi, COVID-19 Özel Sayısı. 2, 95-113.

Demirbaş, D., N. ve Koçak, S. (2020). 2-6 yaş arasında çocuğu olan ebeveynlerin bakış açısıyla covıd-19 salgın sürecinin değerlendirilmesi. Avrasya Sosyal ve Ekonomi Araștırmaları Dergisi, 7 (6) , 328-349.

Di Giuseppe, M., Gemignani, A., \& Conversano, C. (2020). Psychologicalresources against the traumatic experience of COVID-19. Clinical Neu-ropsychiatry: Journal of Treatment Evaluation, 17, 85- 8.

Di Giorgio, E., Di Riso, D., Mioni, G., \& Cellini, N. (2020). The interplay between mothers' and children behavioral and psychological factors during COVID-19: An Italian study. European child \& adolescent psychiatry, 1-12.

Erol, R. (2020). COVID-19 enfeksiyonunun çocuklar üzerindeki psikososyal etkileri. YIU Sağlk Bilimleri Dergisi, 1, 109-114.

Ghosh, R., Dubey, M., Chatterjee, S. Ve Dubey, S. (2020). Impact of COVID-19 on children: special focus on the psychosocial aspect. Minerva Pediatrica. 72(3). 226-35.

Gümüşgül, O. ve Aydoğan, R. (2020). Yeni Tip Koronavirüs-Covid 19 kaynaklı evde geçirilen boş zamanların ev içi rekreatif oyunlar ile değerlendirilmesi. Spor Eğitim Dergisi, 4 (1), 107-114.

Imran, N., Zeshan, M., \& Pervaiz, Z. (2020). Mental health considerations for children \& adolescents in COVID-19 Pandemic. Pakistan Journal of Medical Sciences, 36 (COVID19-S4).

Keleşoğlu, F. ve Adam, F. (2020). Covid-19 sürecinde dijital ebeveynlik ile anne-baba stresi arasında yordayıcı ilişkiler. Online Journal of Technology Addiction and Cyberbullying, 7 (2), 70-102.

Kümbetoğlu, B. (2005). Sosyolojide ve antropolojide niteliksel yöntem ve araştırma. İstanbul: Bağlam Yayıncilık

Mart, M. ve Kesicioğlu, O. S. (2020). COVID-19 Pandemi sürecinde ailelerin evde oyun oynamaya ilişkin görüşleri. Turkish Studies. 15(4). 946-958.

Merriam, S. B. (2013). Nitel araştırma: Desen ve uygulama için bir rehber (3. Baskıdan Çeviri, Çeviri Editörü: S. Turan). Ankara: Nobel Yayın Dağıtım

Miho, A. ve Thévenon, O. (2020). Treating all children equally?: Why policies should adapt to evolving family living arrangements. Report for OECD Social, Employment and Migration Working Papers. Report No. 240.

Olness, K., Mandalakas A. \& Torjesen, K. (2015). How to Help the Children in Disasters. 4th ed. Health Frontiers, Kenyon, USA.

Özel Eğitim ve Rehberlik Hizmetleri Genel Müdürlüğü, (2020). Aileler için çocuklara yardım rehberi. https://orgm.meb.gov.tr/ meb_iys_dosyalar/2020_03/21161548_brosur_cocuk_son.pdf adresinden erişildi.

Pembecioğlu, N. (2020). Covid-19 Medya okuryazarlığı ve çocuklar üzerine etkileri. Çocuk ve Medeniyet, 5 (9), 73-112.

Patton, M.Q. (2014). Nitel Araştırma ve Değerlendirme Yöntemleri. (Çev. M. Bütün ve S. B. Demir) Ankara: Pegem Akademi.

Phelps, C., \& Sperry, L. L. (2020). Children and the COVID-19 pandemic. Psychological Trauma: Theory, Research, Practice, and Policy, 12(S1), S73-S75.

Riegler, L. J., Raj, S. P., Moscato, E. L., Narad, M. E., Kincaid, A., \& Wade, S. L. (2020). Pilot trial of a telepsychotherapy parenting skills intervention for veteran families: Implications for managing parenting stress during COVID-19. Journal of Psychotherapy Integration, 30(2), 290-303.

Şahin, G. (2014). Okul öncesi dönem çocuk kitaplarında görsel bir uyaran olarak resim. International Periodical for the Languages, Literature and History of Turkish or Turkic. 9(3), 1309-1324.

Tarkoçin, S., Alagöz, N. ve Boğa, E. (2020). Okul öncesi dönem çocuklarının pandemi sürecinde (COVID-19) davranı̧̧ değişiklikleri ve farkındalık düzeylerinin anne görüşlerine başvurularak incelenmesi, Turkish Studies. 15(6). 1017-1036.

Toran, M., Sak, R., Xu, Y., Şahin-Sak, İ. T., \& Yu, Y. (2021). Parents and children during the COVID-19 quarantine process: Experiences from Turkey and China. Journal of Early Childhood Research.

UNICEF. (2020). Children at heightened risk of abuse, neglect, and violence amidst intensifying containment measures. https:// www.unicef.org/press-releases/covid-19-children-heightened-risk-abuse-neglect-exploitation-and-violence-amidst adresinden erişildi.

Yavuzer, H. (2000). Çocuğunuzun ilk 6 yll. İstanbul: Remzi Kitabevi.

Yıldırım, A., ve Şimşek, H. (2016). Sosyal bilimlerde nitel araştırma yöntemleri (10. Baskı) Ankara: Seçkin.

Yıldız, S. ve Bektaş, F. (2021). COVID-19 Salgınının Çocukların Boş Zaman Etkinliklerinde Yarattığı Değişimin Ebeveyn Görüşleriyle Değerlendirilmesi. Gazi Beden Eğitimi ve Spor Bilimleri Dergisi, 26 (1), 99-122. 
Yörükoğlu, A. (2002). Çocuk Ruh Să̆lı̆̆ı, İstanbul: Özgür Yayın Dağıtım

Yüksek Usta, S, Gökcan, H. (2020). Çocukların ve annelerinin gözünden Covid-19. International Journal of Social Sciences and Education Research, 6 (2), 187-206.

Wang, G., Zhang, Y., Zhao, J., Zhang, J. \& Jiang, F (2020). Mitigate the effects of home confinement on children during the COVID-19 outbreak. The Lancet, 395, 10228, 945-947.

WHO (2020). Coronavirus disease (COVID-19) advice for the public. https://www.who.int/emergencies/diseases/novelcoronavirus-2019/advice-for-public adresinden erişildi. 


\title{
Investigation of the Case of Pandemic's Psychosocial Impact on Preschool Children Based on Mothers' Views Introduction and purpose
}

\author{
Necla TUZCUOĞLU (iD, Demet AYDIN (iD, Sezgin BALABAN (iD)
}

It is an expected situation for preschool children to show stress and anxiety reactions in the face of difficult life events such as epidemics. Increased stress and anxiety are observed in children and mothers because of the Covid-19 outbreak all over the world. To control this situation, it is necessary to observe and follow the changes in children regularly. In crisis times, children need to see their friends more, also they need to play and communication with them. However, in this process, children find it difficult to cope with emotions. Therefore, children are at risk mentally and physically.

It is not appropriate for children's go out of routine and it has some risks for their physical and mental health. Besides, when the literature is examined, it is seen that the changes caused by the pandemic process in social life negatively effect children in psychosocial terms. These effects were stated to be irritability, gratuitous crying, yelling, and tantrums in children.

When the literature is examined, it is seen that few studies examine the impact of preschool children from the epidemic process. This study is expected to determine the psychosocial effect of the pandemic on preschool children in line with the mothers' views and contribute to the literature. Preschool children are the group most effected by the pandemic process due to their age. This study aims to evaluate the situation of preschool children and their mothers psychosocial effected by the epidemic process following the opinion of their mothers.

\section{Methodology}

Qualitative research design was used in the research. Qualitative research is a research method that keeps 'how' and 'why' questions at the center and enables the researcher to examine a phenomenon or event that cannot be controlled in detail (Yıldırım \& Şimşek, 2016). The main feature of qualitative research is the detailed and in-depth investigation of a situation, the environment, event, individuals, process etc. that effect the situation. (Merriam, 2013). In this study; The qualitative research design was chosen because it was aimed to examine the psychosocial effected status of children and mothers from the pandemic in three categories in depth.

The sample of the study consists of 32 mothers with 48-72 months old children in the central district of Kars province. The data were collected through a semi-structured interview form with 32 mothers and the data were collected. Also, a semi-structured interview form was used as a data collection tool in the study. This form has been prepared in consideration of expert opinions and a children's aid guide for families. This guide was prepared by General Directorate of Special Education and Guidance Services of the Ministry of National Education in 2020. The form consists of a total of 9 questions, open-ended and multiple-choice. Some questions in the interview form: 'Which reactions do you observe in your child during the epidemic process, please indicate. Do you allow your children to ask you questions about the epidemic? What kinds of questions do they usually ask about Covid-19?'etc.

Descriptive analysis technique, one of the content analysis methods, was used in analyzing the data. Descriptive analysis: It is a descriptive, in other words, descriptive analysis of the data by directly citing the information that the participants said, wrote and expressed by the original (Kümbetoğlu, 2005). Participants in the study were coded as E1, E2, E3... E32. The categories and subcategories created within the scope of evaluating the psychosocial influence of children and mothers from the pandemic process in line with the mothers' views were determined as frequency and 
analyzed descriptively.

\section{Results, conclusion and suggestions}

In the mothers effected by the pandemic, mothers stated that they obtained information from various sources of information to cope with the effects of the pandemic process. It is seen that the most used information sources are websites and television. In the second category of the mother-child relationship, it has been observed that mothers frequently talked about the pandemic with their children. Also, it was observed that mothers effectively used the information process to cope with the pandemic process for their children. In the mother-child relationship category, only 12 mothers stated that they do activities at home to give morale to children, 20 mothers stated that they do nothing and should not think about this process for their children. This result shows that the number of mothers who are engaged in activities to support the development of children at home is insufficient and most of them take an unconscious approach to this issue.

As a result of this research, it was tried to determine the psychosocial effection of mothers during the pandemic process and the mother-child relationship.

According to the findings, it was concluded that the pandemic process was effective on children. It was observed that there was a difference in the daily routine activities and reactions of the children. According to the results of the research, some suggestions have been developed for researchers and practitioners.

- Developing programs to reduce the effects of the pandemic process on children.

- Preparing social media and television broadcasts to raise awareness of families and children.

- Providing support services to reduce the effects of the pandemic on children.

- Ensuring that psychologists, child development specialists, pediatricians, social workers, and educators work in cooperation.

- Carrying out information and awareness-raising activities for children by the Ministry of National Education.

- Informing teachers about education and approaches to children during the pandemic process. 